the art in immunohistocytological techniques.

With approximately 100 contributors there is understandably some slight unevenness particularly in the sections on individual diseases. For instance the section on Tsutsugamushi disease is twice as long as the section on common naevi. One of the best chapters is in fact the introductory chapter on technical procedures in immunohistocytology. Many of the technical problems are highlighted and there are clear diagrams illustrating the basics of the different techniques. The book however does not attempt to be a practical manual for doctors or laboratory workers. The first chapter is well referenced, the references to the other chapters being variable. One of the strongest features of this book is the quality of the illustrations. Both the photomicrographs and diagrams are of superb quality and illustrate what excellent results can be achieved in the right hands. One just wonders how many procedures were carried out to enable this number of quality illustrations to be included in one volume!

A Colour Atlas of Dermatoimmunohistocytology can be warmly recommended to anyone interested in the many new and valuable laboratory techniques which are currently being applied to the diagnosis of skin disorders. I am sure every department carrying out such studies will wish to buy a copy. Whether individual workers will wish to buy their own personal copy I think is more doubtful.

NEIL P SMITH

My life before penicillin. By SM Laird. Brauton, Devon. Merlin Books, 1988, (pp 491, illus) $£ 14.95$.

Following the February 1955 meeting of our V.D. Society the author and I were given a lift to Euston station by Dr R R (Dick) Willcox. The conversation focused on the contents of the next issue of the Society's journal. Dr Sydney Laird, in the fourth of his 15 years as editor was giving nothing away. Ever enthusiastic to be in the van, Dick pressed for an informative forecast. Sydney countered with a reader-friendly version of an editor's right to protect his sources. The verbal sparring was worthy of a C P Snow novel. With Euston in sight, Sydney relented. "We don't all have to go as far as East Africa to make a novel observation on treponematoses", a reference to Dick's discovery of njovera (Lancet, 1951;i:558-60). This riposte was delivered with a puckish, teasing friendliness which ensured its acceptance. Dick's curiosity was to be satisfied only after another two weeks when he read Sydney's "Yaws in Manchester" ( $\mathrm{Br} J$ Venereal Dis 1955;31:30-32).

This vignette gives some idea of the man who has favoured us with the first half of his autobiography. It is a rare treat.

With increasing blindness the author taught himself to type and this book is a product of his new-found skill.

Dr Laird was born and bred in Kilmacolm on the southern shores of the Clyde estuary. $\mathrm{He}$ was the youngest of three sons of a country GP. He coped with the death of his mother during his teens, the resultant maledominated household, and more than a decade of travelling daily by train to school, University and hospitals in the gloomy Glasgow of the Great Depression. Sport helped to sustain him, firstly running, and then tennis. His passion for rugby has been life-long, as have been some of his student friendships. He qualified in 1934.

All but one of his housemanships were in Liverpool hospitals. He pursued experience and learning with the "work ethic" application common to many Scots of his time. Some measure of this comes with his first year in a non-resident post in venereology in Liverpool. During that time he acquired an $M D$, and a DPH and the Fellowship of the Glasgow College of Physicians and Surgeons.

Most of his six years in the wartime Royal Army Medical Corps were devoted to his chosen speciality. He distinguished himself while Western Command Venereologist by his detailed research and discovery of syringe-transmitted jaundice. Within a few years the condition was recognised world-wide and prevented.

In the midst of all this he found time to embark on a happy marriage, found a family and find satisfaction in wide reading with biography and the precision of the law amongst his favourites.
As might be expected from an exeditor the writing flows smoothly and with a clarity of crystal quality. It is a joy to read. Where drama appears it is studiously controlled; masterly understatements are tersely delivered and the wit has a sharp, easy and graceful quality that gives real pleasure.

Sydney Laird of course was only one of many Scots who took the road to England during the hundred years from the mid-19th century. His story will be essential reading for future historians comparing the contributions of such immigrants with those arriving later from the Commonwealth and the new ones now beginning to appear from Europe. Scots of Sydney Laird's calibre will be hard to beat.

When men like Dick Willcox and Sydney Laird were at the height of their chosen speciality, a venereologist was jokingly defined as a person with many acquaintances but few friends. I would venture to suggest that the reason you haven't heard this before is due to Dr Laird. My abiding memory of this book will be his capacity for friendships. This gift fitted him uniquely for his speciality. His patients must have been well served. By reading this book you will share their great good fortune.

RS MORTON

Urinary Tract infection and inflammation by Jackson E Fowler with contributions by Mary Lee and Anthony A Caldamone. (Pp 339, $£ 55.50$ hardback). Chicago. Year Book Medical Publishers Inc 1989 (ISBN 0-8151-3265-4).

My heart sank when I read the introduction to this book. It was vague and verbose and as I was unable to "slot-in" to the author's conceptual framework I initially understood little of it. This is a shame as it rather coloured my impression of the rest of the book, so my advice to potential readers is to leave it out.

This initial hurdle overcome, the style of the book becomes more pleasing and the content more informative with each succeeding chapter. The first three chapters provide a nonclinical overview of the subject, with a chapter on anatomy followed by chapters on antimicrobial agents and bac- 
teriology. These I feel should have been presented in a different order, with antimicrobial agents following bacteriology, and an attempt should have been made to highlight the clinical importance of these sections with, for example, therapeutics and basic pharmacology being blended to show their relevance in the management of urinary tract infections.

Other chapters cover such topics as urinary tract infections and urethral syndrome in women, bacterial and non-bacterial prostatitis in men, as well as urinary tract infection in childhood, the elderly, pregnancy and diabetes. Some sections such as those on infected renal calculi and genitourinary tuberculosis have little relevance to the daily practice of genitourinary medicine in the UK and the sections on sexually transmitted diseases although adequately covered were fairly uninspiring.

At times I felt the data presented were inaccurate such as "about $15 \%$ of men with gonococcal urethritis will develop urethral stricture disease" (accompanied by a 1965 reference!), and "approximately $40 \%$ of men with acute urethritis have gonococcal infections" (certainly not in Leicester in 1989 and I guess not in many parts of the USA even when the naval boat comes in!). These anachronisms together with a few factual errors made me feel uneasy about some of the less familiar information presented. Nevertheless, I feel this is a useful book either to dip into or for those genitourinary physicians with an interest in "cystitis", but I am relieved my copy of the book was complimentary because I would certainly have browsed through its competitors before parting with my money.

PETER FISK

Acyclovir therapy for herpesvirus infections Edited by DA Baker (\$1 19.50. Pp 344). New York. Marcel Dekker. (ISBN 0-8247-8091-4) 1990.

The 24 contributors to this book who are all from the United States, write well in clear English and fortunately the problem of widely differing literary styles which can be obtrusive in multi author volumes does not arise here in any way, making the text very readable.
The first chapters are devoted to detailed accounts of the molecular basis for acyclovir's antiviral activity and then to the many carefully performed preclinical and clinical safety studies so essential in the evaluation of any new drug. The general safety of the drug is confirmed though more information is required concerning its use in pregnancy and for long term suppression.

The management of $\mathrm{HSV}$ infections of the eye, mouth and hand are separately dealt with in very practical detail. The chapter on hand infections stresses the problems often met with in virus isolation from this site, skin puncture generally being required to achieve success. The not uncommon and often troublesome association of hand infections with lymphoedema of hand or arm presumably resulting from lymphatic damage is discussed along with the value of suppressive therapy in health care workers. (The risks of infection to others here are highlighted by the case of a dental hygienist with herpes of the hand who infected 20 of 46 patients seen over a 4 day period.)

The management of genital herpes is covered in two chapters which include good brief accounts of the virology, epidemiology, and clinical course of the illness. Diagnosis and prevention are not forgotten whilst the recommended treatment are clearly explained and do not stop at the prescription of acyclovir.

No one has so far been able to offer a treatment which will completely prevent recurrent disease and the whole question of suppressive therapy with acyclovir in this situation is examined in considerable detail with common sense recommendations.

The difficult and complex questions posed by herpes in pregnancy and herpetic illness in the neonate and infancy occupy nearly a third of the book and this section deserves to be widely read. It will be of especial interest to obstetricians and pediatricians.

The use of acyclovir in the treatment of encephalitis, in HIV infection and immunosuppression in general, and its use in zoster, varicella, and EB virus infection are all carefully and critically considered.

The book is well bound and printed (though an episode of "double vision" experienced by the reviewer turned out to be due to the visibility of the print from the other side of a very thin page; only two pages were so affected). The text throughout is well referenced and there is a good index. It should be read by anyone who treats patients with the disease. The price will probably ensure that most of us will have to read it in the library.

JK OATES NOTICE

\section{International Pathogenic Neisseria Conference}

The Seventh International Pathogenic Neisseria Conference will be held on 9-14 September 1990 in West Berlin, Federal Republic of Germany. For further details please contact Dr. Mark Achtman, Max-Planck-Institut für molekulare Genetik, Ihnestr. 73, 1000 Berlin 33, Federal Republic of Germany. Tel: (004930) 8307 262, telefax: (004930) 8307382 . 